\title{
Assessment of associated impacts the inappropriate disposal of coffee waste on the behavior escape of the earthworms
}

\author{
Sérgio Thode Filho ${ }^{1}$, Leonardo Corrêa de Souza ${ }^{2}$, Emanuele Nunes de Lima Figueiredo \\ Jorge $^{3}$, Morgana de Luna Mortoni da Silva ${ }^{4}$, Aline Santos de oliveira Guedes ${ }^{5}$, Heider Alves \\ Franco $^{6}$ \\ 1,3Professor at the Federal Institute of Education, Science and Technology of Rio de Janeiro - IFRJ, Campus Duque de \\ Caxias, RJ, Multidisciplinary Laboratory Waste Management - LMGR. sergio.thode@ifrj.edu.br \\ ${ }^{2}$ Graduation Student at the University UNIGRANRIO, Rio de Janeiro, RJ, Multidisciplinary Laboratory Waste \\ Management - LMGR \\ 4,5Student of the Technical Course in Petroleum e Gas - IFRJ, Campus Duque de Caxias, RJ Multidisciplinary \\ Laboratory Waste Management - LMGR
}

${ }^{6}$ Professor at the Federal Institute of Education, Science and Technology of Rio de Janeiro - IFRJ, Campus Pinheiral, RJ, Multidisciplinary Laboratory of Agro-Environmental Technology - LAMTAA

\begin{abstract}
Earthworms are one of the organisms used in ecotoxicity tests. The species (Eisenia fetida) is the most common. This preference is due to its ability to poorly convert chemically broken organic wastes into stabilized material. This work aimed to investigate the earthworm avoidance response, simulating the inappropriate disposal of this residue in soil, besides identifying the $\mathrm{pH}$ of these samples after the avoidance test. For this experiment we worked with two groups. The test group, used percentages of the coffee waste added to the mass of sandy and loamy soil. It can be seen that there are excessively high prevention and control measures in the disposal of petroleum residues and agricultural agrochemicals than in coffee waste. Therefore, these results highlight the importance of greater control and prevention of inappropriate coffee waste disposal. However, although the limiting dosage for earthworms was significantly higher than that of the other pollutants observed ( $10 \%$ sandy soil and $5 \%$ loamy soil), and because it was a solid residue of organic origin, the coffe waste also rendered soil unsuitable for habitat of the earthworms.
\end{abstract}

Keywords: Coffee waste, Escape, Ecotoxicity.

\section{Introduction}

Coffee has been consumed for over 1000 years and is currently one of the most widely consumed beverages around the world. According to the International Coffee Organization more than 151,624 million the bags of $60 \mathrm{~kg}$ of this compound were consumed worldwide in 2016 (INTERNATIONAL COFFEE ORGANIZATION, 2017). 
Two species are of significant economic importance Coffea arabica (Arabica) providing $75 \%$ of the world production and Coffea canephora (Robusta), which provides $25 \%$ of the world production (VARNAM, SUTHERLAND, 1994).

The coffee beverage is prepared with hot water and, when it comes to espresso coffee, it uses pressure (between 10 and 20 bar) to favor the extraction of compounds that contribute to a higher sensorial quality of the drink. The insoluble material resulting from the extraction of the beverage from hot coffee is called coffee grounds. The sludge is a residue that still has no commercial value and is commonly discarded. In recent years, the need for waste mitigation and environmental protection has stimulated research aimed at the use of sludge as a source of new compounds of industrial interest. For every $1 \mathrm{~kg}$ of soluble coffee, $2 \mathrm{~kg}$ of moist soil is generated, with about $75 \%$ to $80 \%$ moisture (ZUORRO e LAVECCHIA, 2012).

The residual biomasses of coffee and other beverages generated in coffee shops, restaurants, residences, bars and among others do not have registers due to the difficulty of quantifying this type of waste in different places (FREITAS, 2000; VEGRO e CARVALHO, 2006; RAMALAKSHMI et al., 2009; PANUSA et al., 2013).

To analyze the toxic effects for substance or mixed substances improperly discarded should be performed toxicity tests that aim to predict the potential impact of a xenobiotic (toxic agent) on environment (FLOHR et al., 2005). For such tests, certain organisms are used and they are called test organisms. They experience adverse effects when in contact with toxic substances. Among the adverse effects can be included from genetic alterations and immobility, until deformities and mortality (PIMENTEL et al., 2011).

Eathrworms are one of the organisms used in ecotoxicity testing and the red-of-California or manure worm (Eisenia fetida) is the most common. This preference is due to its ability to convert organic waste little chemically broken into stabilized material. In addition, they have extensive playback capabilities and rapid growth. In this sense, these worms are an important link in terrestrial trophic web, providing resources for a wide variety of organisms, including birds, mammals, reptiles and amphibians. They represent a good alternative to achievement of ecotoxicological tests because they are simple to handle, easy to find as well as good indicators for the soil quality (ANDREA, 2010; CORREIA; MOREIRA, 2010; DITTBRENNER et al., 2011).

The contaminants in the soil can be adsorbed on the mineral particles, organic matter and soil solution and, therefore, the earthworms come into contact with the compounds through the ingestion of the soil (SPADOTTO et al., 2004; CORREIA; MOREIRA, 2010).

Thus in view of the large amount of coffee waste generated after consumption and inappropriate disposal about soil, kitchen sink, landfills and via the sewage, this work aimed to investigate the earthworm avoidance response, simulating the inappropriate disposal of this residue in soil, besides identifying the $\mathrm{pH}$ of these samples after the avoidance test.

\section{Material and methods}

\subsection{Materials}

According to Table 1, it was found that the soil with sandy texture has a slightly neutral $\mathrm{pH}$, while the $\mathrm{pH}$ of the loamy soil shows acid. The soil with sandy texture presents a value (S) for the sum of the bases $(8,8)$ much higher than that found in soil with loamy texture $(3,7)$. The presence of $\mathrm{Al} 3+$ in loamy soil is discreet. The percentage of C. Org. $(17,9)$ in the sandy soil is 3.7 times superior to the loamy. In relation to the $(\mathrm{V} \%)$, it is perceived that the sandy soil presents an excellent fertility condition, while the loamy soil presents a low fertility.

Table 1: Physical-chemical characterization of soils 


\begin{tabular}{|c|c|c|c|c|c|c|c|c|c|c|c|}
\hline $\begin{array}{c}\text { Soil } \\
\text { Texture }\end{array}$ & $\begin{array}{c}\mathrm{pH} \\
\mathrm{H}_{2} \mathrm{O}\end{array}$ & $\mathrm{Ca}^{2+}$ & $\mathrm{Mg}^{2+}$ & $\mathbf{K}^{+}$ & $\begin{array}{l}\mathrm{Na}^{+} \\
\text {lol. }_{\text {c. }} \mathrm{dn}\end{array}$ & $\mathrm{Al}^{3+}$ & $\mathrm{H}^{+}+\mathrm{Al}^{3+}$ & $\begin{array}{c}P \\
\left(\mathrm{mg} \mathrm{dm}^{3}\right)\end{array}$ & V & C.org & $\mathbf{N}$ \\
\hline Sandy & 7.4 & 5.0 & 2.2 & 1.3 & 0.3 & 0.0 & 0.0 & 0.4 & 100 & 17.9 & 1.8 \\
\hline Loamy & 5.3 & 2.9 & 0.5 & 0.1 & 0.2 & 0.3 & 0.0 & 3.0 & 53 & 4.8 & 0.5 \\
\hline
\end{tabular}

\subsection{Methods}

\subsubsection{Earthworm escape test}

The avoidance test (ABNT NBR 17512-1, 2011) were performed for both types of soil using transparent plastic boxes $(28.8 \mathrm{~cm} \times 10.8 \mathrm{~cm} \times 4.2 \mathrm{~cm}$ ). Ten adult earthworms (Eisenia fetida $\mathrm{sp)}$ for each box exposed at the same time to a control soil and to a soil containing the test substances. Test and control soil were placed into each test box as well as the earthworms and presented to them a choice between the test soil and the control soil. After 48 hours, was evaluated the percentage of earthworms present in each soil.

For this experiment we worked with two groups. The test group, was used percentages of the coffee waste added to the mass of sandy and loamy soil. The treatments the test group was: (a) $1 \%(2.5 \mathrm{~g}+250 \mathrm{~g}$ soil); (b) $5 \%$ (12.5 g $+250 \mathrm{~g}$ soil); (c) $10 \%$ (25 g $+250 \mathrm{~g}$ soil); (d) $15 \%$ (37.5 g + 250 g soil); (e) $20 \%$ (50 g + 250 g soil); (f) $30 \%$ (75 g + 250 g soil); (g) $40 \%$ (100 g + 250 g soil); (h) $50 \%(125 \mathrm{~g}+250 \mathrm{~g}$ soil $)$ and control group, only $250 \mathrm{~g}$ soil. Each experiment performed in triplicate for each soil.

The tests response for the two soil types containing coffee waste was calculated in terms of avoidance percentage per concentration. The avoidance percentage was calculated based on the following formula: $A=[(C-T) / N] \times 100$, where $C$ is the number of animals found in the control soil, $\mathrm{T}$ and the number of animals found on the test soil, and $\mathrm{N}$ the total number of animals used per treatment (for each concentration tested). A positive and indicative avoidance result is a negative attraction by the concentration of the active ingredient tested. According to the norm, $0 \%$ of escape indicates animal attraction to the chemical substance evaluated. On the other hand, a soil is considered toxic when more than $80 \%$ of exposed organisms prefer the control soil (leakage $>60 \%$ ) (ABNT, 2011).

\subsection{2 $\mathrm{pH}$ analysis}

The $\mathrm{pH}$ parameter in water of sandy and loamy soils was evaluated according to the by Embrapa (1997). In addition, the multi-parameter analyzer (COMBO 5 - AKSO) was used.

\subsection{Statistical analysis}

To analyze the statistical significance for dosages between the triplicates was chosen the Tukey test. The same was used to test for significant differences between the triplicates results (COSTA NETO, 1977; MILLER; MILLER, 1993). All calculations and graphs presented in this work were performed by BioEstat 5.0 and SigmaPlot 12.5 software. 


\section{Results and discussion}

According to Technical Standard NBR 10.004 Solid waste - Classification (ABNT, 2004), this coffee waste is classified as: Class II A, Not Hazardous - Not Inert.

In sandy soil, the rapid earthworm avoidance response in coffee waste dosages less than $25 \mathrm{~g} / 250 \mathrm{~g}$ soil (10\%) did not provoke the avoidance by more than 60\% (Figure 1). However starting this dosage soil became toxic to earthworms. A quadratic relation was observed between the coffee waste dosage and the avoidance.

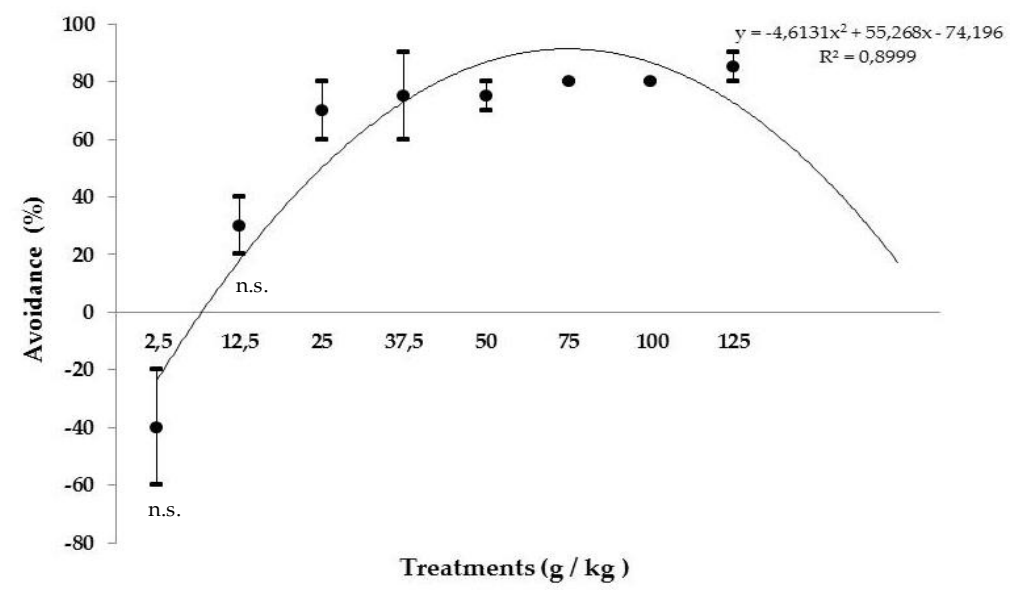

Figure 1 - Eisenia fetida avoidance response contaminated with different coffee waste dosages in sandy soil. Average and standard deviation bars, Tukey test, $\mathrm{p} \leq 0.05$; n.s. = not significant.

In the case of loamy soil, the earthworms tolerance was slightly lower. The second dosage of $5 \%(12,5 \mathrm{~g} / 250 \mathrm{~g})$ resulted in rapid earthworm avoidance response greater than $60 \%$ (Figure 2). It is observed that this starting dosage in loamy soil, became toxic to earthworms. A quadratic relation too was observed between the coffee waste dosage and the avoidance.

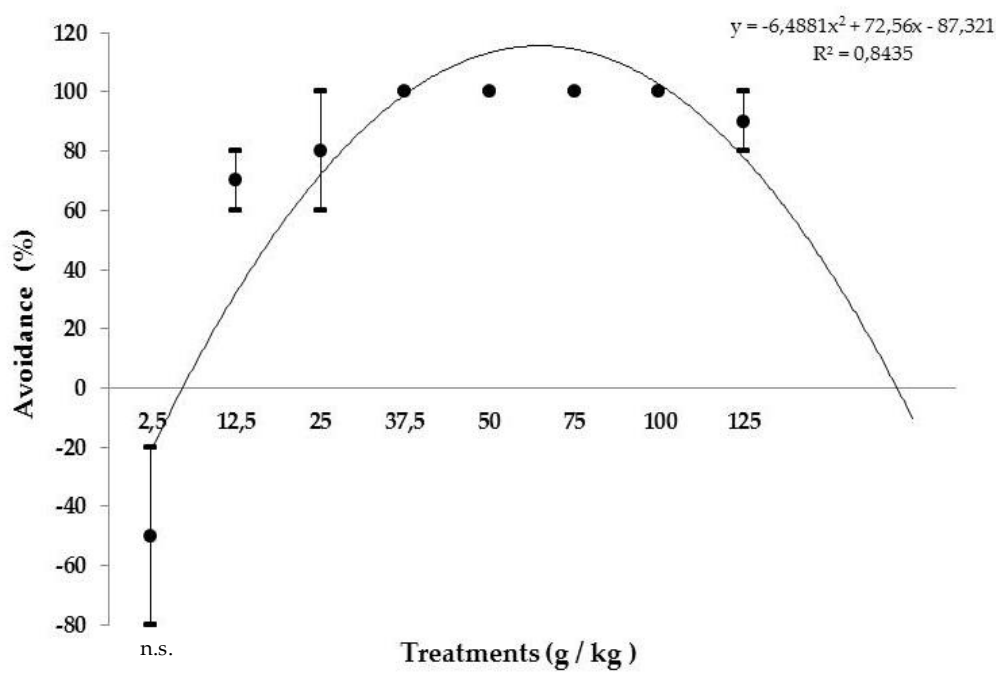

Figure 2 - Eisenia fetida avoidance response contaminated with different coffee waste dosages in loamy soil. Average and standard deviation bars, Tukey test, $\mathrm{p} \leq 0.05$; n.s. = not significant.

The $\mathrm{pH}$ values in sandy and loamy soils after the escape test are shows in Table 2. A decrease in the $\mathrm{pH}$ values in both soils was observed as the coffee waste mass increased. The dose 
with 40 and $50 \%$ of coffee grounds, further acidified the sandy soil. Additionally, the loamy soil the acidification process started with the first treatment (1\%). The treatment with $30 \%$ left the soil with an extremely acidic character. Significant differences were observed between the test groups for both soils by the Tukey test $(\mathrm{p}<0.05)$.

Table 2: pH analysis of soils after earthworm escape test

\begin{tabular}{|c|c|c|c|c|c|c|c|c|}
\hline \multirow{2}{*}{$\begin{array}{c}\text { Soil } \\
\text { Texture }\end{array}$} & \multicolumn{8}{|c|}{$\mathrm{pH}$} \\
\hline & $1 \%$ & $5 \%$ & $10 \%$ & $15 \%$ & $20 \%$ & $30 \%$ & $40 \%$ & $50 \%$ \\
\hline Sandy & $7.4 \mathrm{a}$ & $7.3 a$ & $7.3 \mathrm{a}$ & $7.0 \mathrm{~b}$ & $7.0 \mathrm{~b}$ & $6.8 b$ & $6.2 \mathrm{c}$ & $5.8 \mathrm{~d}$ \\
\hline Loamy & $4.8 \mathrm{a}$ & $3.7 b$ & $3.7 \mathrm{~b}$ & $3.6 b$ & $3.6 \mathrm{~b}$ & $3.2 \mathrm{c}$ & $3.4 \mathrm{c}$ & $3.4 \mathrm{c}$ \\
\hline
\end{tabular}

Shaefer (2003) reports that this ability to react to adverse environments is related to the high number of chemoreceptors, concentrated in the prostomio (dorsal prominence that covers the mouth) and in the anterior segments of the earthworm body, as well as the distribution of epidermal papillae and endings Nerves around body segments that contribute to the ability of earthworms to respond to the chemical stimuli of the environment.

By the way, Stephenson et al. (1998) state that the epithelium of the mouth region harbors groups of sensory cells that can be stimulated by chemicals related to palatability. This sensitivity of chemical detection, coupled with locomotor skills, gives earthworms the ability to avoid adverse habitats. In the present study, the soils acidity caused by the excessive presence of coffee waste.

Grue et al. (2002) state that chemical stressors or extreme natural conditions can compromise biological processes, diverting the optimal range of variation required by the worm or other test organism, which may exhibit a stress-induced response.

Earthworms have the ability to quickly distinguish different types of food and react to a variety of chemical stimuli (EDWARS; BOHLEN, 1996; GRUE et al., 2002). Considering the result of the soils analysis after the escape test (Table 2), it is understood that the coffee waste acts to inhibit the soil condition as a habitat for the earthworm. It is also understood that the alteration in the acidity of the soil caused by the presence of the pollutant is directly related to the behavior of the earthworm's escape. This relationship was verified for both soils, but in loamy soil the tolerance to the pollutant was lower.

This work is a pioneer in the application of the test of earthworm avoidance to evaluate the impact of coffee waste in soil, therefore these results could not be compared to the previous works. In contrast, the impact of coffee waste was compared to other pollutants frequently related to environmental contamination, which were also evaluated by the earthworm avoidance test.

Yeardley et al. (1996) when performing the earthworm avoidance test with $\mathrm{KCl}$ element, found that only $0.0015 \mathrm{~g} / 250 \mathrm{~g}$ soil caused avoidance to the control soil greater than $60 \%$. With respect to the element $\mathrm{NH}_{4} \mathrm{Cl}, 0.15 \mathrm{~g} / 250 \mathrm{~g}$ soil. There is therefore a greater tolerance of the test organism to this element.

A study by García-Santos and Karin Keller-Forrer (2011) found that in agrochemicals, pesticides, such as carbofurans (0.0025 g / $250 \mathrm{~g}$ soil); Chlorpyrifos $(0.01 \mathrm{~g} / 250 \mathrm{~g}$ soil) and Metamidophós ( $0.2 \mathrm{~g} / 250 \mathrm{~g}$ of soil) showed earthworm avoidance greater than $60 \%$ with small doses in soil.

Wang et al (2010) conducted a earthworm avoidance test with petroleum sludge and found that the limiting dose was $4.25 \mathrm{~g} / 250 \mathrm{~g}$ soil. However, a study by Thode Filho et al (2017) 
about that residual vegetable oil is 4.33 times less impacting earthworms than oil sludge (18.40 $\mathrm{g}$ / 250 g soil); although the residual vegetable oil also made soil improper for the earthworm habitat.

\section{Conclusion}

It can be seen that there are excessively high prevention and control measures in the disposal of petroleum residues and agricultural agrochemicals than in coffee waste. Therefore, these results highlight the importance of greater control and prevention of inappropriate coffee waste disposal. However, although the limiting dosage for earthworms was significantly higher than that of the other pollutants observed ( $10 \%$ sandy soil and $5 \%$ loamy soil), and because it was a solid residue of organic origin, the coffe waste also rendered soil unsuitable for habitat of the earthworms.

\section{Bibliographic references}

ANDREA, M.M.D. O uso de minhocas como bioindicadores de contaminação de solos. Acta Zoológica Mexicana (nueva serie), n. 2, p. 95-107, 2010.

ASSOCIAÇÃO BRASILEIRA DE NORMAS TÉCNICAS. NBR 10.004: Resíduos sólidos Classificação. Rio de Janeiro: 2004.

ASSOCIAÇÃO BRASILEIRA DE NORMAS TÉCNICAS. NBR ISO 17512-1. Qualidade do solo Ensaio de fuga para avaliar a qualidade de solos e efeitos de substâncias químicas no comportamento. Parte 1: Ensaio com minhocas (Eisenia fetida e Eisenia andrei). Rio de Janeiro: 2011.

CORREIA, F.V.; MOREIRA, J.C. Effects of glyphosate and 2,4-D on earthworms (Eisenia foetida) in laboratory tests, Bull. Environ. Contam. Toxicol., v. 85, p. 264-268, 2010.

COSTA NETO, P. L. O. Estatística. São Paulo: Edgard Blücher, 1977. 264p.

DITTBRENNER, N.; SCHMITT, H.; CAPOWIEZ, Y.; TRIEBSKORN, R. Sensitivity of Eisenia fetida in comparison to Aporrectodea caliginosa and Lumbricus terrestris after imidacloprid exposure. Body mass change and histopatology, J. Soil Sediments, v. 11, p. 1000-1010, 2011.

EDWARDS, C. A., BOHLEN, P .J. Biology and Ecology of Earthworms. Chapman and Hall, Londres, $3^{\mathrm{a}}$ ed, 426 p., 1996.

EMBRAPA - EMPRESA BRASILEIRA DE PESQUISA AGROPECUÁRIA. Manual de métodos de análises de solos. Rio de Janeiro: Embrapa-CNPS. 1997. 212p

FLOHR.L. et al. Classificação de resíduos sólidos industriais com base em testes ecotoxicológicos utilizando Daphnia magna: uma alternativa. Biotemas, Florianópolis, v. 18, n. 2, p. 7-18, 2005.

FREITAS, S.P.; MONTEIRO, P.L.; LAGO, R.C.A. Extração do óleo da borra do café solúvel com etanol comercial. I Simpósio de Pesquisa dos cafés do Brasil, Industrialização. Poços de Caldas. p.740$743,2000$. 
GARCÍA-SANTOS, G.; SCHEIBEN, D.; BINDER, C.R., 2011. The weight method: a new screening method for estimating pesticide deposition from knapsack sprayers in developing countries. Chemosphere v. 82 n. 11, p. 1571-1577.

GRUE, C. E.; GARDNER, S. C.; GIBERT, P. L. On the significance of pollutant-induced alterations in the behaviour of fish and wildlife. In: Dell'Omo, G. (ed.), Behavioural Ecotoxicology. John Wiley \& Sons Ltd, Reino Unido, 463 p., 2002.

International Coffee Organization, 2015. World Coffee Consumption. 〈http://www.ico.org/prices/new-consumption-table.pdf〉 (Accessed 19 July 2017)

MILLER, J.C. \& MILLER, J.N. Statistics for analytical chemistry. 3a ed. Chichester: Ellis Horwood. 233p., 1993.

PANUSA, A.; PETRUCCI, R.; MARROSU, G.; LAVECCHIA, R.; ZUORRO, A. Recovery of Natural Antioxidants from Spent Coffee Grounds. Journal of Agricultural and Food Chemistry .v. 61, p.4162 -4168, 2013.

PIMENTEL, M.F. et al. O uso de Artemia sp. como organismo-teste para avaliação da toxicidade das águas residuárias do beneficiamento da castanha de caju antes e após tratamento em reator biológico experimental. Journal of the Brazilian Society of Ecotoxicology, v. 6, n. 1, p. 15-22, 2011.

RAMALAKSHMI, K.; RAO, L.J.M.; TAKANO -ISHIKAWA, Y.; GOTO, M. Bioactivities of low grade green coffee and spent coffee in different in vitro model systems. Food Chemistry. India. v.115, p.79 -85, 2009.

SCHAEFER, M. Behavioural endpoints in earthworm ecotoxicology. Journal of Soils and Sediments, v. 3, n. 2, p. 79-84, 2003.

SPADOTTO, C.A.; GOMES, M.A.; LUCHINI, L.C.; ANDREA, M. de. Monitoramento do risco ambiental de agrotóxicos: princípios e recomendações. Embrapa Meio Ambiente. Documentos 42, Jaguariúna, 2004. 29p.

STEPHENSON, G.; KAUSHIK, A.; KAUSHIK, N. K.; SOLOMON, K. R.; STEELE, T.; SCOGGINS, R. P. Use of an avoidance-response test to assess the toxicity of contaminated soils to earthworms. In: SHEPPARD, S.; BEMBRIDGE, J.; HOLMSTRUP, M.; POSTHUMA, L. (eds). Advances in Earthworm Ecotoxicology, p. 67-81, Pensacola: SETAC Press, 1998.

THODE-FILHO, S., PAIVA, J.L. de, FRANCO, H.A., PEREZ, D.V., MARQUES, M.R.C. de. Environmental impacts caused by residual vegetable oil In the soil-plant system. Ciência e Natura Journal, (2017). [no prelo]

VARNAM, A.H., Sutherland, J.P. Beverages: Technology, Chemistry and Microbiology. London, p. 191-255, 1994.

VEGRO, C. L. R.; CARVALHO, F. C. Disponibilidade e utilização de resíduos gerados no processamento agroindustrial do café. Inf. Econ., v. 24, p. 9 -16, 2006. 
YEARDLEY, R; GAST, L.; LAZORCHAK, J. The potential of an earthworm avoidance test for evaluation of hazardous waste sites. Environmental toxicology and chemistry, v. 15, n. 9, p. $1532-$ 1537, 1996.

ZUORRO, Antonio; LAVECCHIA, Roberto. Spent coffee grounds as a valuable source of phenolic compounds and bioenergy. Journal of Cleaner Production, v. 34, p. 49-56, 2012.

WANG, $\mathrm{S}$ et al. Ecotoxicity assessment of aged petroleum sludge using a suite of effects-based end points in earthworm Eisenia fetida. Environmental monitoring and assessment, v. 169, n. 14, p. 417-428, 2010. 